\title{
PENEMPATAN PEGAWAI DI LEMBAGA PENDIDIKAN ISLAM PERSPEKTIF AL-QUR'AN DAN HADITS
}

\author{
Muhammad Roihan Alhaddad
}

Sekolah Tinggi Ilmu Tarbiyah (STIT) Raudhatul Ulum Sakatiga Jalan Kh. Mohammad Harun, Sakatiga, Indralaya, Kabupaten Ogan Ilir, Sumatera Selatan 30662

E-mail: roihan.alhaddad@gmail.com

\section{Ahmad Syukri Kasful Anwar US.}

Universitas Islam Negeri (UIN) Sulthan Thaha Saifuddin Jambi Jl. Jambi - Muara Bulian No.KM. 16, Simpang IV Sipin, Telanaipura, Kota Jambi, Jambi 36361

\begin{tabular}{|c|c|c|}
\hline Diterima: & Revisi: & Disetujui: \\
13 Mei 2019 & 23 Mei 2019 & 30 Mei 2019 \\
\hline
\end{tabular}

\begin{abstract}
This paper discusses the importance of placing employees in an educational institution, clearly the purpose of this HR placement is to place the right people and positions in accordance with their interests and abilities, so that existing human resources are productive. Appropriate placement is a way to optimize abilities, skills towards good work performance for the workers themselves. So that in the right position will be able to help the company in achieving the expected goals. Criteria that must be met in the placement of employees in the implementation include: knowledge, ability, and Attitude. While the placement of employees according to the verses of the Qur'an and Hadith includes: knowledge, ability/expertise, not asking for office (Hadith), strong, one group/ group, high work ethic, and trustful.
\end{abstract}

Keyword: Islamic education, placement of employees, and Islamic education institutions

\begin{abstract}
Abstrak
Tulisan ini membahas tentang pentingnya menempatkan pegawai pada sebuah lembaga pendidikan, secara jelas tujuan penempatan SDM ini adalah untuk menempatkan orang yang tepat dan jabatan yang sesuai dengan minat dan kemampuannya, sehingga sumber daya manusia yang ada menjadi produktif.
\end{abstract}


Penempatan yang tepat merupakan cara untuk mengoptimalkan kemampuan, keterampilan menuju prestasi kerja yang baik bagi pekerja itu sendiri. Sehingga dalam posisi jabatan yang tepat akan dapat membantu perusahaan dalam mencapai tujuan yang di harapkan. Kriteria-Kriteria yang harus dipenuhi dalam Penempatan pegawai dalam pelaksanaannya antara lain: pengetahuan, kemampuan dan sikap. Sedangkan Penempatan pegawai menurut ayat al-Qur'an dan Hadits meliputi: pengetahuan, kemampuan/ keahlian, tidak meminta jabatan (Hadits), kuat, satu kalangan/golongan, etos kerja tinggi, dan amanah.

Kata Kunci: Pendidikan Islam, Penempatan pegawai, dan Lembaga Pendidikan Islam

\section{A. Pendahuluan}

Dalam era persaingan suatu organisasi memiliki kemampuan dalam berbagai macam aspek dan merumuskan strategi dalam menghadapi perubahan yang terjadi di organisasi baik itu organisasi bisnis pemerintah dan organisasi lainnya diharapkan akan menjadi tujuan. Tercapainya tujuan organisasi akan tergantung pada bagaimana Sumber Daya Manusia yang ada di dalam organisasi tersebut dapat mengembangkan kemampuan baik di bidang manajerial, hubungan antar manusia maupun teknis operasional.

Berbicara tentang pelaksanaan tugas ini, maka peranan prestasi kerja adalah sangat menentukan kualitas seseorang pegawai dalam suatu perusahaan/organisasi. Sumber daya yang penting dari suatu organisasi adalah pekerjaanya. Pekerjaan merupakan sumber daya yang kaya dan siap digunakan. Dari semua harta kekayaan, maka sumber daya manusialah satu-satunya harta yang besar potensinya bagi tingkat produktifitasnya.

Secara jelas, tujuan penempatan pegawai di lembaga pendidikan Islam ini adalah untuk menempatkan orang yang tepat dan jabatan yang sesuai dengan minat dan kemampuannya, sehingga sumber daya manusia yang ada menjadi produktif. Penempatan yang tepat merupakan cara untuk mengoptimalkan kemampuan, keterampilan menuju prestasi kerja yang baik bagi pekerja itu sendiri. Sehingga dalam posisi jabatan yang tepat akan dapat membantu sekolah dalam 
mencapai tujuan yang di harapkan. Langkah awal dalam menghasilkan sumber daya manusia yang terampil dan handal, perlu adanya suatu perencanaan dalam menentukan pegawai yang akan mengisi pekerjaan yang ada dalam lembaga pendidikan yang bersangkutan. Keberhasilan dalam pengadaan tenaga kerja terletak pada ketepatan dalam penempatan pegawai, baik penempatan pegawai baru maupun pegawai lama pada posisi jabatan baru.

Adapun Inti dari staffing tak lain dan tak bukan adalah untuk memperoleh dan menempatkan "the right man on the right place". Oleh karena itu, setelah fungsi manajemen berupa pengorganisasian dibahas, maka dilanjutkan dengan staffing (penempatan), sehingga aktifitas dalam sebuah organisasi bisa dilaksanakan oleh orang-orang yang tepat. Maka dalam tulisan ini akan di bahas tentang staffing atau penempatan pegawai di lembaga pendidikan Islam dalam ayat alQur'an dan Hadis.

\section{B. Penempatan Pegawai dan Beberapa Konsepnya}

Banyak yang berpendapat bahwa penempatan merupakan akhir dari proses seleksi. Apabila seluruh proses seleksi telah ditempuh dan lamaran seseorang diterima, akhirnya seseorang memperoleh status sebagai pegawai dan ditempatkan pada posisi tertentu untuk melaksanakan tugas atau kerjaan tertentu. ${ }^{1}$

Penempatan adalah proses penugasan atau pengisian jabatan atau penugasan kembali pegawai pada tugas atau jabatan baru atau jabatan yang berbeda. Penugasan ini dapat berupa penugasan pertama untuk pegawai baru direkrut, tetapi dapat juga melalui promosi, pengalihan, dan penurunan jabatan atau bahkan pemutusan hubungan kerja. ${ }^{2}$

Sedangkan pegawai adalah kekayaan atau aset utama dari setiap perusahaan/organisasi. Penempatan pegawai adalah kegiatan yang

${ }^{1}$ Sondang P. Siagian, Manajemen Sumber Daya Manusia, (Jakarta: Bumi Aksara, 2008), h. 168.

${ }^{2}$ Hariandja, Manajemen Sumber Daya Manusia, cet. ke-3, (Jakarta: PT. Grafindo, 2002), h. 45 
dilakukan oleh manajer untuk menempatkan seorang pegawai pada pekerjaan dan jabatan yang ada pada organisasi. Peran pegawai sangat menentukan berhasil tidaknya organisasi mencapai sasarannya. Perusahaan harus selalu berusaha untuk memperoleh dan menempatkan pegawai yang berkualitas pada setiap jabatan dan pekerjaan supaya pelaksanaan seleksi berjalan dengan baik, pegawai berdaya guna serta berhasil guna. ${ }^{3}$

Adapun beberapa kriteria yang harus dipenuhi dalam pelaksanaan penempatan pegawai menurut Bernardin dan Russel ${ }^{4}$ meliputi beberapa hal, yaitu;

1) Pengetahuan, merupakan suatu kesatuan informasi terorganisir yang biasanya terdiri dari sebuah fakta atau prosedur yang diterapkan secara langsung terhadap kinerja. Sebuah fungsi pengetahuan seseorang dapat diperoleh melalui pendidikan formal, pendidikan informal, membaca buku dan lain-lain. Pengetahuan yang dimiliki oleh pegawai diharapkan dapat membantu dalam melaksanakan tugas dan tanggung jawab pekerjaannya, oleh karena itu pegawai dituntut untuk memiliki pengetahuan yang sesuai dengan pekerjaannya.

2) Kemampuan, kemampuan menunjukan kesanggupan, kecakapan seseorang untuk melaksanakan tugas dan pekerjaan yang dibebankan kepadanya. Setiap pekerjaan menuntut pengetahuan, keterampilan dan sikap tertentu. Kemampuan sangat penting karena bertujuan untuk mengukur prestasi kerja pegawai, maksudnya dapat mengukur sejauh mana pegawai bisa sukses dalam melakukan tugas dan pekerjaannya. Hal ini berkaitan dengan kenyataan bahwa setiap jenis pekerjaan menuntut pengetahuan, keterampilan dan sikap tertentu agar dapat melakukan pekerjaan dengan baik yang akan berpengaruh terhadap peningkatan prestasi kerja pegawai tersebut.

3 S.P. Melayu Hasibuan, Manajemen Sumber Daya Manusia, (Jakarta: PT. Bumi Aksara, 2003), cet. ke-6, h. 27

4 Bernandin, H. John and Joyce E. A. Russel, Human Resources Management, (MacGraw-Hill, Inc, Singapore, 1993). 
3) Sikap, merupakan pernyataan evaluatif yang baik dan menguntungkan, hal ini menyangkut mengenai obyek, orang atau peristiwa dimana sikap dapat mencerminkan bagaimana seseorang merasakan sesuatu (misalnya benar, salah, setuju, tidak setuju).

\section{Pegawai di Lembaga Pendidikan Pesantren}

Secara etimologi, lembaga merupakan asal sesuatu, acuan, sesuatu yang memberi bentuk pada yang lain, badan atau organisasi yang bertujuan mengadakan suatu penelitian keilmuan atau melakukan sesuatu usaha. Berdasarkan pada pengertian di atas dapat dipahami bahwa lembaga mengandung dua arti, yaitu: 1) pengertian secara fisik, materil, kongkrit, dan 2) pengertian secara non-fisik, nonmateril, dan abstrak. Selain itu, lembaga juga sering disebut dengan istilah institute (dalam pengertian fisik), yaitu sarana atau organisasi untuk mencapai tujuan tertentu, dan lembaga dalam pengertian nonfisik atau abstrak disebut institution, yaitu suatu sistem norma untuk memenuhi kebutuhan. Lembaga dalam pengertian fisik disebut juga dengan bangunan, dan lembaga dalam pengertian non fisik disebut dengan pranata. ${ }^{5}$

Sementara itu, secara terminologi, Amir Daiem mendefinisikan lembaga pendidikan dengan orang atau badan yang secara wajar mempunyai tanggung jawab terhadap pendidikan. Rumusan definisi yang dikemukakan Amir Daiem ini memberikan penekanan pada sikap tanggung jawab seseorang terhadap peserta didik, sehingga dalam realisasinya merupakan suatu keharusan yang wajar bukan merupakan keterpaksaan. Adapun lembaga pendidikan Islam secara terminologi dapat diartikan suatu wadah atau tempat berlangsungnya proses pendidikan islam. Berdasarkan pada definisi di atas dapat disimpulkan bahwa lembaga pendidikan itu mengandung pengertian kongkrit berupa sarana dan prasarana dan juga pengertian yang

5 Ramayulis, Ilmu Pendidikan Islam, (Jakarta: Kalam Mulia, 2011), Cet ke.9, h. 277. 
abstrak, dengan adanya norma-norma dan peraturan-peraturan tertentu, serta penananggung jawab pendidikan itu sendiri. ${ }^{6}$

Berdasarkan pada uraian di atas, dalam kontek Islam, lembaga pendidikan memiliki klasifikasi dari yang tingkatannya kecil sampai pada yang tingkatan lebih besar. Abdul Mujib dan Jusuf Mudzakkir7 mengemukakan beberapa jenis lembaga pendidikan Islam, yaitu; keluarga, masjid, pondok pesantren dan madrasah.

\section{Keluarga Sebagai Lembaga Pendidikan Islam}

Dalam Islam, keluarga dikenal dengan istilah usrah, nasl, 'ali, dan nasb. Keluarga dapat diperoleh melalui keturunan (anak, cucu), perkawinan (suami, istri), persusuan, dan pemerdekaan. Sebagai pendidikan yang pertama dan utama, pendidikan keluarga dapat mencetak anak agar mempunyai kepribadian yang kemudian dapat dikembangkan dalam lembaga-lembaga berikutnya, sehingga wewenang lembaga-lembaga tersebut tidak diperkenankan mengubah apa yang telah dimilikinya, tetapi cukup dengan mengombinasikan antara pendidikan yang diperoleh dari keluarga dengan pendidikan lembaga tersebut, sehingga masjid, pondok pesantren dan sekolah merupakan tempat peralihan dari pendidikan keluarga.

\section{Masjid}

Secara harfiah, masjid adalah "tempat untuk bersujud". Namun, dalam arti terminologi, masjid diartikan sebagai tempat khusus untuk melakukan aktivitas ibadah dalam arti yang luas. Pendidikan Islam tingkat pemula lebih baik dilakukan di masjid sebagai lembaga pengembangan pendidikan keluarga, sementara itu dibutuhkan sutau lingkaran (lembaga) dan ditumbuhkannya. Dewasa ini, fungsi masjid mulai menyempit, tidak sebagaimana pada zaman Nabi SAW. Hal itu terjadi karena lembaga-lembaga sosial keagamaan semakin memadat, sehingga masjid terkesan sebagai tempat ibadah shalat saja. Pada

\footnotetext{
${ }^{6}$ Ramayulis, Ilmu Pendidikan.... , h. 278

7 Abdul Mujib dan Jusuf Mudzakkir, Ilmu Pendidikan Islam, (Jakarta: Kencana, 2008), Cet ke 2, h.. 226-234
} 
mulanya, masjid merupakan sentral kebudayaan masyarakat Islam, pusat organisasi kemasyarakatan, pusat pendidikan, dan pusat pemukiman, serta sebagai tempat ibadah dan I'tikaf.

Al-'Abdi menyatakan bahwa masjid merupakan tempat terbaik untuk kegiatan pendidikan. Dengan menjadikan lembaga pendidikan dalam masjid, akan terlihat hidupnya Sunnah-sunnah Islam, menghilangkan segala bid'ah, mengembangkan hukum-hukum Tuhan, serta menghilangnya stratafikasi status sosial-ekonomi dalam pendidikan. Karena itu, masjid merupakan lembaga kedua setelah lembaga pendidikan keluarga.

\section{Pondok Pesantren}

Kehadiran kerajaan Bani Umaiyah menjadikan pesatnya ilmu pengetahuan, sehingga anak-anak masyarakat Islam tidak hanya belajar di masjid tetapi juga pada lembaga-lembaga yang ketiga, yaitu "kuttab" (pondok pesantren). Kuttab, dengan karateristik khasnya, merupakan wahana dan lembaga pendidikan Islam yang semula sebagai lembaga baca dan tulis dengan sistem halaqah (sistem wetonan). Pada tahap berikutnya kuttab mengalami perkembangan pesat karena didukung oleh dana dari iuran masyarakat serta adanya rencana-rencana yang harus dipatuhi oleh pendidik dan peserta didik.

Di Indonesia, istilah kuttab lebih dikenal dengan istilah "pondok pesantren" yaitu suatu lemabaga pendidikan Islam yang di dalamnya terdapat seorang kiai (pendidik) yang mengajar dan mendidik para santri (peserta didik) dengan sarana masjid yang digunakan untuk menyelenggarakan pendidikan tersebut, serta didukung adanya pemondokon atau asrama sebagai tempat tinggal para santri.

\section{Madrasah}

Madrasah merupakan bentuk isim masdar dari kata darasa yang berarti sekolah atau tempat untuk belajar. Dalam perkembangan selanjutnya, madrasah sering dipahami sebagai lembaga pendidikan yang berbasis keagamaan. Adapun sekolah sering dipahami sebagai 
lembaga pendidikan yang berbasis pada ilmu pengetahuan pada umumnya. Madrasah sebagai lembaga pendidikan merupakan fenomena yang merata di seluruh negara, baik pada negara-negara Islam, maupun negara lainnya yang di dalamnya terdapat komunitas masyarakat Islam Sebagian ahli sejarah berpendapat, bahwa madrasah sebagai lembaga pendidikan Islam muncul dari penduduk Nisapur, tetapi tersiarnya melalui Perdana Menteri Bani Saljuk yang bernama Nidzam al-Muluk, melalui Madrasah Nidzamiah yang didirikannya pada tahun 1065 M.8 Selanjutnya, Gibb dan Kramers menuturkan bahwa pendiri madrasah terbesar setelah Nizam al-Mulk adalah Shalah al-Din al-Ayyubi. ${ }^{9}$

\section{Penempatan Pegawai Perspektif al-Quran dan Hadis}

Islam telah mengatur persolan kehidupan dunia dengan detail, termasuk dalam memanage perihal penempatan kepegawaian. Terdapat beberapa kriteria yang harus dipenuhi dalam menyeleksi atau menempatkan pegawai menurut al-Qur'an dan Hadis.

1. Pengetahuan

Islam mendorong umatnya untuk menempatkan tenaga kerja atau pegawai yang telah dipilih atau diseleksi berdasarkan pengetahuan, pengalaman dan kemampuan teknis yang dimiliki. Hal ini sesuai dengan firman Allah SWT dalam Quran Surat Yusuf sebagai berikut;

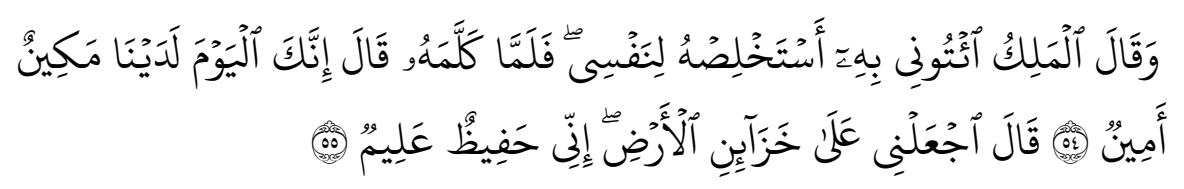

Artinya:

Dan raja berkata: "Bawalah Yusuf kepadaku, agar aku memilih dia sebagai orang yang dekat kepadaku". Maka tatkala raja telah

${ }^{8}$ Abuddin Nata, Ilmu Pendidikan Islam, (Jakarta: Kencana, 2010). h. 199.

${ }^{9}$ Abdul Mujib dan Jusuf Mudzakkir, Ilmu Pendidikan..., h.. 241 
bercakap-cakap dengan dia, dia berkata: "Sesungguhnya kamu (mulai) hari ini menjadi seorang yang berkedudukan tinggi lagi dipercayai pada sisi kami". Berkata Yusuf: "Jadikanlah aku bendaharawan negara (Mesir); sesungguhnya aku adalah orang yang pandai menjaga, lagi berpengetahuan." (QS. Yusuf: 54-55)

Ayat tersebut di atas, menjelaskan bahwa Nabi Yusuf a.s. sangat tahu kemampuan yang beliau miliki dan beliau ingin membagi kemampuan tersebut untuk kepentingan masyarakat. Dalam ayat tersebut juga dijelaskan bahwa dalam hal penempatan tenaga kerja baru untuk memegang jabatan penting, diperlukan pengalaman dan pengetahuan yang luas serta kemampuan untuk melaksanakan tugas.

\section{Keahlian atau Kemampuan}

Berkaitan dengan keahlian atau kemampuan yang menjadi salah satu prasyarat dalam penempatan pegawai telah di atur dalam QS. anNisa' ayat 58, yang artinya; "Sesungguhnya Allah menyuruh kamu menyampaikan amanat kepada yang berhak menerimanya, dan (menyuruh kamu) apabila menetapkan hukum di antara manusia supaya kamu menetapkan dengan adil. Sesungguhnya Allah memberi pengajaran yang sebaik-baiknya kepadamu. Sesungguhnya Allah adalah Maha Mendengar lagi Maha Melihat. (QS. an-Nisa', 58)

Ayat di atas menjadi dasar tentang sebuah amanat yang wajib disampaikan atau ditunaikan kepada yang berhak menerimanya. Atau dengan kata lain, memberikan amanat kepada ahlinya, yaitu orang yang benar-benar mempunyai keahlian dibidang tersebut. Jadi, dalam penempatan seorang pegawai juga harus dilihat dari kemampuan dan keahlian seorang pegawai tersebut, sehingga apabila seorang pegawai ditempatkan sesuai dengan kemampuan dan keahlian yang dimilikinya, maka ia akan lebih mudah dan cepat dalam menjalankan serta menyelesaikan segala tugas dan tanggung jawab yang telah dibebankan kepadanya, sehingga tujuan dari lembaga tempat ia bekerja akan lebih mudah tercapai. 
Demikian juga hadits nabi yang menjelaskan tentang penempatan pegawai dengan melihat aspek keahlian pada suatu bidang yang dibutuhkan.

$$
\text { اذا ضيعت الامانة فانتظرالساعة. قال كيف اضاعتها يارسول الله ؟ قال اذا اسند }
$$

Artinya:

"Ketika engkau menyia-nyiakan amanah, maka tunggulah kehancuran. Dikatakan hai Rasulullah, apa yang membuatnya sia-sia? Rasul Bersabda, ketika suatu pekerjaan diserahkan kepada orang yang bukan ahlinya maka tunggulah kehancuran". (HR. Bukhari). ${ }^{10}$

Dalam hadis yang lain juga telah di riwayatkan, bahwa "Sesungguhnya Allah sangat mencintai orang yang jika melakukan sesuatu pekerjaan, dilakukan secara itqan (tepat, terarah, jelas, dan tuntas". (H.R. Thobroni).11

Berdasarkan pada kedua hadis di atas dapat dijelaskan bahwa ketika suatu jabatan diduduki oleh seorang yang bukan ahlinya maka bukan kebaikan yang diperoleh. Akan tetapi, kemungkinan besar yang akan timbul adalah kerusakan karena orang tersebut tidak memiliki keahlihan dibidang tersebut. Dalam manajemen syariah keahlian saja tidak cukup, tetapi juga harus diimbangi dengan etos kerja dan tanggung jawab yang tinggi terhadap suatu pekerjaan. Jika salah satu dari aspek tersebut tidak dimiliki oleh pegawai, maka ketimpangan yang akan terjadi

3. Tidak meminta Jabatan

Berdasarkan riwayat yang disampaikan oleh $\mathrm{Abu}$ Musa $\mathrm{Al}$ Asy'ari, sebagaimana yang telah dikutip oleh Jusmaliani, bahwa;

10 Hadiyah Salim, Tarjamah Mukhtarul Ahadits, (Bandung: PT. Al-Ma'arif, 1985), h. 169.

${ }^{11}$ Hadiyah Salim, Tarjamah Mukhtarul..., h. 80. 


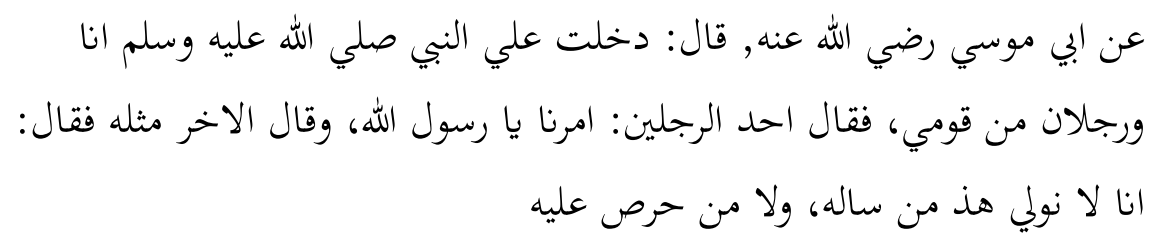

Artinya:

Dari Abu Musa Radhiyallahu anhu dia berkata, "Saya masuk menemui Nabi Shallallahu 'alaihi wa sallam bersama dengan dua orang dari kaumku, lalu salah seorang dari kedua orang itu berkata, "Jadikanlah (angkatlah) kami sebagai amir (pejabat) wahai Rasulullâh!" Kemudian yang seorang lagi juga meminta hal yang sama. Maka beliau Shallallahu 'alaihi wa sallam bersabda, "Sesungguhnya kami tidak akan mengangkat sebagai pejabat orang yang memintanya dan tidak juga orang yang tamak terhadap jabatan itu".12

Berkaitan dengan topik di atas, Muslim juga meriwayatkan, bahwa ketika Abu Dzar Al-Ghifari meminta Rasulullah untuk menjadikannya sebagai gubernur pada salah satu wilayah kekuasaan Islam, Rasulullah menanggapi permintaan ini dengan berkata: "Hai Abu Dzar, sesungguhnya engkau lemah dan aku suka sesuatu yang ada pada dirimu sebagaimana dalam diriku. Sesungguhnya jabatan itu amanah, dan dihari kiamat, ia akan berubah menjadi kehinaan dan penyesalan, kecuali diserahkan pada orang yang berhak dan mampu menunaikan tugas-tugas yang terkait dengan jabatan itu. ${ }^{13}$

Hadits ini menunjukkan sebab larangan meminta jabatan, yakni kelemahan dari Abu Dzar Al-Ghifari ra. Kelemahan itu dapat membuat seseorang tidak bisa menjalankan amanahnya sehingga akan membawa kehancuran dan penyesalan di akhirat. Sehingga larangan ini adalah khusus bagi mereka yang lemah.

Kedua hadits di atas memperlihatkan bagaimana Rasulullah saw memilih, yang pertama beliau tidak memberikan jabatan kepada yang 76.

12 Jusmaliani, Pengelolaan Sumber Daya Insani, (Jakarta:Bumi Aksara, 2011), h.

13 Jusmaliani, Pengelolaan Sumber..., h. 76. 
sangat menginginkannya dan hadits yang kedua beliau mengingatkan bahwa jabatan adalah amanah. Dari sisi yang berbeda dapat diartikan bahwa dalam kasus dua hadits ini, mereka yang meminta jabatan tersebut tidak mengukur kemampuan dirinya sendiri. ${ }^{14}$

\section{Kuat}

Kriteria penempatan pegawai ini sebagaimana yang telah di firmankan oleh Allah dalam surat al-Qashash; 26

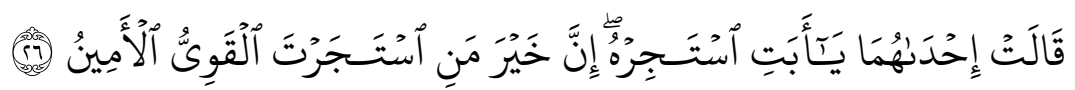
Artinya:

Salah seorang dari kedua wanita itu berkata: "Ya bapakku ambillah ia sebagai orang yang bekerja (pada kita), karena sesungguhnya orang yang paling baik yang kamu ambil untuk bekerja (pada kita) ialah orang yang kuat lagi dapat dipercaya" (Q.S. al-Qashash: 26).

Lafadz ista'jarta pada ayat di atas, berarti menarik dia untuk dijadikan pekerja atau pegawai. Lafadz ijarah diartikan sebagai jualbeli jasa (upah-mengupah) yakni mengambil manfaat tenaga kerja manusia. Suatu usaha memilih tenaga kerja untuk dipekerjakan pada bidang tertentu yang dalam perkembangannya lebih populer dengan istilah seleksi. Dalam usaha mencari tenaga kerja, al-Qur'an memberikan penjelasan bahwa standar kepatutan seseorang untuk mendapatkan pekerjaan didasarkan kepada keahlian serta kemampuan yang dimiliki. Dalam ayat tersebut juga terdapat lafadz alQowiyyu yang berarti kuat (sehat jasmani dan rohani) dan lafadz alAmin yang diartikan dapat dipercaya. Dengan demikian, dapat dipahami bahwa dalam memilih para pekerja harus yang memiliki kekuatan baik fisik maupun non fisik tergantung jenis pekerjaan yang dilowongkan, jujur dalam perkataan dan memiliki sifat amanah (dapat dipercaya).

\footnotetext{
${ }^{14}$ Jusmaliani, Pengelolaan Sumber..., h. 77.
} 
Pada ayat di atas, Allah SWT memberikan penjelasan bahwa seorang pekerja yang baik adalah orang yang kuat dan dapat dipercaya. Dalam tafsir al-Misbah dijelaskan bahwa kekuatan yang dimaksud adalah kekuatan dalam berbagai bidang. Karena itu, terlebih dahulu harus dilihat bidang apa yang akan ditugaskan kepada pelamar yang dipilih. Selanjutnya kepercayaan yang dimaksud adalah integritas pribadi, yang menuntut adanya sifat amanah sehingga tidak merasa bahwa apa yang ada dalam genggaman tangannya merupakan milik pribadi, tetapi milik pemberi amanat yang harus dipelihara dan bila diminta kembali, maka harus dengan rela mengembalikannya. ${ }^{15}$

\section{Satu Kalangan atau Golongan}

Penempatan pegawai juga harus mempertimbangkan dari faktor kesamaan, baik kesamaan dalam agama, pemikiran, dan golongan. Hal ini untuk menjaga kerahasiaan yang ada di dalam sebuah lembaga pendidikan. Mengenai hal ini, al-Qur'an telah menjelaskan dalam surat ali-Imran ayat 118 tentang kriteria memilih pegawai.

"Hai orang-orang yang beriman, janganlah kamu ambil menjadi teman kepercayaanmu orang-orang yang, di luar kalanganmu (karena) mereka tidak henti-hentinya (menimbulkan) kemudharatan bagimu. Mereka menyukai apa yang menyusahkan kamu. Telah nyata kebencian dari mulut mereka, dan apa yang disembunyikan oleh hati mereka adalah lebih besar lagi. Sungguh telah Kami terangkan kepadamu ayat-ayat (Kami), jika kamu memahaminya". (Q.S ali-Imron:118)

Allah telah melarang hamba-hamba-Nya yang beriman untuk menjadikan orang-orang munafik sebagai teman kepercayaan. Yakni mereka akan membukakan rahasia dan segala yang tersembunyi untuk musuh orang-orang Islam. Dan orang-orang munafik itu, dengan segenap daya dan kekuatannya, tidak henti-hentinya (menimbulkan) kemudaratan bagi orang-orang yang beriman. Yakni selalu

15 M. Quraish Shihab, Tafsir Al-Misbah Pesan, Kesan dan Keserasian al-Qur'an, (Jakarta: Lentera Hati, 2002), h. 334. 
berusaha keras untuk menyelisihi dan menjerumuskan mereka ke dalam bahaya dengan segala cara, serta melakukan berbagai tipu muslihat yang dapat dilakukan. Mereka juga menyukai hal-hal yang dapat menyulitkan, melukai dan menyusahkan orang-orang yang beriman.

Dari ayat di atas sudah sangat jelas bagaimana seorang pemimpin untuk memilih pegawai yang tepat yaitu dengan melihat latar belakangnya sesuai atau tidak dengan kriteria di atas. Misalkan seorang pimpinan pesantren mengangkat pegawai dari alumni, keluarga ustadz/zah, dari pesantren tersebut sehingga kerahasiaan pesantren akan terjaga dengan baik.

\section{Etos Kerja Tinggi}

Pada bagian ini, Islam sangat mendorong setiap muslim untuk selalu bekerja keras, bersungguh-sungguh mencurahkan tenaga dan kemampuan dalam menjalankan berbagai pekerjaan yang telah menjadi tanggung jawabnya. Dapat dikatakan bahwa seorang muslim dalam bekerja harus bersungguh-sungguh dan penuh semangat. Dengan kata lain harus bekerja keras (hard worker) sehingga produktif dan inovatif. ${ }^{16}$ Sebagaimana firman Allah SWT, yang artinya:

"Dan kamu lihat gunung-gunung itu, kamu sangka dia tetap di tempatnya, padahal ia berjalan sebagai jalannya awan.

(Begitulah) perbuatan Allah yang membuat dengan kokoh tiaptiap sesuatu; sesungguhnya Allah Maha Mengetahui apa yang kamu kerjakan". (QS. an-Naml: 88)

Dari ayat di atas kita dapat memahami bahwa menempatkan pegawai juga harus melihat dari aspek semangat dalam bekerja yang tinggi (etos kerja). Ketika seorang pegawai mempunyai kriteria ini maka semua pekerjaan akan selesai tepat pada waktunya.

16 Abdul Hamid Mursi, SDM yang Produktif: Pendekatan al-Qur'an dan Sains, (Jakarta:Gema Insani, 1997), h. 114 


\section{Amanah}

Seorang pekerja muslim yang profesional harus memiliki sifat amanah, terpercaya dan bertanggung jawab, bekerja dengan sungguhsungguh dan mencurahkan segala potensi yang dimiliki demi untuk mewujudkan tujuan organisasi dan bukan hanya mencari kepentingan pribadinya, sehingga muncul jiwa amanah yaitu mampu menjalankan tugas dan bertanggung jawab atas tugas yang diberikan. Sebagaimana dijelaskan dalam firman Allah, yang artinya;

"Hai orang yang beriman, janganlah kamu mengkhinati Allah dan Rasul (Muhammad) dan juga jngan kamu mengkhianati amanatamanat yang dipercayakan kepadamu, sedang kamu mengetahui". (Q.S. al-Anfal: 27)

Berdasarkan pada ayat tersebut, dapat dikatakan bahwa dalam hal penempatan pegawai harus memilih yang amanah, seseorang tidak boleh berkhianat dalam menunaikan amanahnya padahal mereka adalah orang yang mengetahui. Jadi dalam proses pengerjaan tugasnya seorang pegawai harus menyelesaikannya dengan baik dan benar karena tugas ataupun tanggung jawab yang telah diberikan kepadanya itu merupakan suatu amanah yang harus dilaksanakan dengan sebaik-baiknya.

Amanah merupakan faktor penting untuk menentukan kepatutan dan kelayakan seorang calon pegawai. Hal ini bisa diartikan dengan melaksanakan segala kewajiban sesuai dengan ketentuan Allah dan takut terhadap aturan-Nya. Selain itu, melaksanakan tugas yang dijalankan dengan sebaik mungkin sesuai dengan prosedurnya, tidak diwarnai dengan unsur nepotisme, tindak kezaliman, penipuan, intimidasi, atau kecenderungan terhadap golongan tertentu. Calon pegawai harus dipilih berdasarkan kepatutan dan kelayakan. Dalam Islam, prosesi pengangkatan pegawai harus berdasarkan kepatutan dan kelayakan calon pegawai atas pekerjaan yang dijalaninya. ${ }^{17}$

17 Ahmad Ibrahim Abu Sinn, Manajemen Syariah: Sebuah Kajian Historis dan Kontemporer, (Jakarta: PT. Raja Grafindo Persada), h. 106. 


\section{E. Kesimpulan}

Penempatan pegawai merupakan bentuk kegiatan yang dilakukan oleh manajer untuk menempatkan seorang pegawai pada pekerjaan dan jabatan yang ada pada organisasi. Peran pegawai sangat menentukan berhasil tidaknya perusahaan mencapai sasarannya.

Adapun kriteria-kriteria yang harus dipenuhi dalam penempatan pegawai dalam pelaksanaannya di lembaga pendidikan Islam, meliputi; aspek pengetahuan, kemampuan, dan sikap. Sementara itu, penempatan pegawai perspektif ayat al-Qur'an dan Hadits meliputi beberapa hal, yaitu: dalam QS. Yusuf 54-55 terkandung makna seorang pegawai harus memiliki pengetahuan; dalam QS. an-Nisa ayat 58, seseorang harus memiliki kemampuan (keahlian); dalam sebuah dinyatakan bahwa seseorang haruslah tidak meminta jabatan (Hadits); dalam Q.S. al-Qashash ayat 26 dikatakan bahwa seorang pegawai harus kuat; dalam QS. ali-Imran ayat 118, seorang pegawai harus berasal dari satu kalangan atau golongan; dalam QS. an-Naml ayat 88 seorang pegawai harus memiliki etos kerja tinggi; dan dalam QS. al-Anfal ayat 27, seorang pegawai harus memiliki sikap amanah.[]

\section{Daftar Pustaka}

Abu Sinn, Ahmad Ibrahim. Manajemen Syariah: Sebuah Kajian Historis dan Kontemporer, Jakarta: PT. Raja Grafindo Persada.

Bernandin, H. John and Joyce E. A. Russel. Human Resources Management, MacGraw-Hill, Inc, Singapore, 1993.

Hariandja. Manajemen Sumber Daya Manusia, Jakarta: PT. Grafindo, 2002.

Hasibuan, S.P. Melayu. Manajemen Sumber Daya Manusia, Jakarta: PT. Bumi Aksara, 2003 
Jusmaliani. Pengelolaan Sumber Daya Insani, Jakarta: Bumi Aksara, 2011.

Mujib, Abdul dan Mudzakkir, Jusuf. Ilmu Pendidikan Islam, Jakarta: Kencana, 2008.

Mursi, Abdul Hamid. SDM yang Produktif: Pendekatan al-Qur'an dan Sains, Jakarta: Gema Insani, 1997.

Nata, Abuddin. Ilmu Pendidikan Islam. Jakarta: Kencana, 2010.

Ramayulis. Ilmu Pendidikan Islam, Jakarta: Kalam Mulia, 2011.

Salim, Hadiyah. Tarjamah Mukhtarul Ahadits, Bandung: PT. Al-Ma'arif, 1985.

Shihab, M. Quraish. Tafsir Al-Misbah Pesan, Kesan dan Keserasian alQur'an, Jakarta: Lentera Hati, 2002.

Siagian, Sondang P. Manajemen Sumber Daya Manusia, Jakarta: Bumi Aksara, 2008 